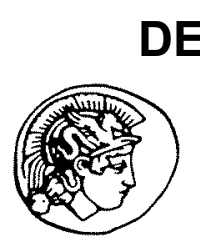

PERGAMON
Journal Article

Available online at www.sciencedirect.com

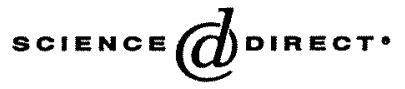

Biomass and Bioenergy 24 (2003) $337-349$

\title{
Enhancing the soil organic matter pool through biomass incorporation
}

\author{
Felipe G. Sanchez ${ }^{\mathrm{a}}$, Emily A. Carter ${ }^{\mathrm{b}, *}$, John F. Klepac ${ }^{\mathrm{b}}$ \\ ${ }^{a}$ USDA Forest Service, Southern Research Station, P.O. Box 12254, Research Triangle Park, NC 27709, USA \\ ${ }^{b}$ USDA Forest Service, Southern Research. Station, 520 Devall Drive, Auburn University, AL 36849-54I8, USA
}

Received 2 December 2001; received in revised form 11 June 2002; accepted 10 September 2002

\begin{abstract}
A study was installed in the Upper Coastal Plain of South Carolina, USA that sought to examine the impact of incorporating downed slash materials into subsoil layers on soil chemical and physical properties as compared with the effect of slash materials left on the soil surface. Baseline levels of slash were estimated by establishing transects within harvested stands and estimating the quantity of down wood and stumps. An equivalent quantity of biomass and two times the baseline levels were incorporated into subsurface soil layers by a CMI RS 500B reclaimer/stabilizer. Two sites were examined which differed in soil textural composition: sandy vs. clay. Site differences had no impact on machine productivity and machine costs were estimated at \$US $521 \mathrm{ha}^{-1}$ and \$US $633 \mathrm{ha}^{-1}$ on the 'sandy' and 'clay' sites, respectively. The feasibility of the CMI for biomass incorporation is low due to high unit area costs but increased machine productivity would reduce costs and improve its potential. Biomass incorporation improved carbon and nutrient content of each site, especially on the sandy site. Slash levels had an impact on nutrient content but the differences were not statistically significant. For the sandy site, improvements in soil physical properties were evident in response to incorporation and machine planting operations. Bulk density and soil strength were reduced in response to biomass incorporation and tillage to levels that would not limit root production. The differences in soil physical response between incorporated treatments were minimal and not statistically significant.

Published by Elsevier Science Ltd.
\end{abstract}

Keywords: Biomass; Carbon; Nitrogen; Bulk density; Cone index; Machine costs; Machine production

\section{Introduction}

Forests of the southern United States are dependent on soil organic matter (SOM) dynamics for adequate nutrition and water. In fact, soil carbon (C) content and distribution may strongly influence the long-term sustainable productivity of a site. Carbon contained

\footnotetext{
* Corresponding author. Tel.: +1-334-826-8700; fax: +1-334821-0037.

E-mail addresses: fsanchez@fs.fed.us (F.G. Sanchez), eacarter@fs.fed.us (E.A. Carter), jklepac@fs.fed.us (J.F. Klepac).
}

in SOM is a significant component of the terrestrial $\mathrm{C}$ pool, hence, the effect of forest management practices on SOM has ramifications for species composition and production of the forest and terrestrial $\mathrm{C}$ balances. The challenge is to develop forest management approaches that sustain or enhance the productivity potential and thereby enhance $\mathrm{C}$ sequestration. Forests store 20-100 times more $\mathrm{C}$ per unit area in aboveground biomass and soils than croplands [1]. Managed forests have a particularly high potential to sequester large amounts of $\mathrm{C}$, and thus are potentially a significant sink for atmospheric carbon dioxide $\left(\mathrm{CO}_{2}\right)$. The 
forest soil condition in the southeastern United States may be characterized by reduced SOM content due to inherent soil conditions and past agricultural practices [2]. These soils have considerable afforestation and productivity potential which has not been translated into soil $\mathrm{C}$ gains.

An effective means of increasing and stabilizing SOM is through the application of organic soil amendments such as logging residues, which are usually readily available. In the southeastern United States, unincorporated logging residue will decompose rapidly and will be lost as carbon dioxide $\left(\mathrm{CO}_{2}\right)$ [3-5]. Estimated rates of decomposition for forest detritus ranges from $0.072 \mathrm{yr}^{-1}$ in the Piedmont region of South Carolina, to $0.11 \mathrm{yr}^{-1}$ in Texas, to $0.32 \mathrm{yr}^{-1}$ in North Carolina $[4,5]$. If left on the surface, it is unlikely that this decomposing detritus will significantly contribute to the mineral soil carbon pool $[2,6]$. Buford et al. [7] presented a conceptual model describing the effects of different fates of standing biomass on $C$ sequestration. In their model, they assumed that leaving the litter and logging residue on the soil surface would leave site productivity unchanged. Alternatively, incorporating the litter and logging residues into the soil would increase site productivity by improving physical properties and nutrient retention and cycling processes of the soil. Early observations on a study site where forest slash was incorporated into the soil showed a marked increase in SOM $[8,9]$. Although their study involved shallow tilling $(20 \mathrm{~cm})$ of forest slash into the soil, Sanchez et al. [8] found that, $1.5 \mathrm{yr}$ after study installation, some treatments increased soil $\mathrm{C}$ and $\mathrm{N}$ by almost $100 \%$ compared with pre-treatment values. Analysis of the macro-organic matter $(>0.53 \mathrm{~m})$ suggested that there would continue to be an influx of $\mathrm{C}$ into the soil.

Short-term increases in SOM can be easily accomplished through biomass incorporation, but the effect must be long-term, which implies an increased size of the recalcitrant SOM pool. Development of the recalcitrant SOM pool is strongly influence by soil physical properties $[10,11]$, particularly particle size. Clay stabilizes carbon by various mechanisms including (1) adsorption of organic molecules on the clay surface [12], (2) preservation of microbial biomass [13,14], and (3) promotion of a higher efficiency of use of metabolic products by soil biota [13]. The importance of clays on SOM stabilization is especially pronounced in warmer climates $[15,16]$. In long-term ecosystem studies conducted in the upper Piedmont of South Carolina, the rate of accretion of soil $\mathrm{C}$ seemed dependent on soil properties, particularly texture and drainage. Richter et al. [2] showed only a small accretion of soil $\mathrm{C}\left(0.07 \mathrm{Mg} \mathrm{C} \mathrm{ha}^{-1} \mathrm{yr}^{-1}\right)$ in a 44-year-old loblolly pine plantation planted on a well-drained, sandy loam soil. In contrast, Van Lear et al. [4] demonstrated a much larger rate of soil $\mathrm{C}$ accretion $\left(0.47 \mathrm{MgC} \mathrm{ha}^{-1} \mathrm{yr}^{-1}\right.$ ) on a 55-year-old loblolly pine plantation on a Pacolet soil (fine, kaolinitic, thermic Typic Kanhapludult) where the $A$ and $B$ horizons had been eroded leaving an exposed clayey $C$ horizon.

While SOM is recognized to be the primary source of available nitrogen $(N)$ and provides as much as $65 \%$ of the total soil phosphorus (P) [17], it is the nutrient turnover rate that is more relevant to forest productivity [18-20]. Linking nutrient availability to biomass production and allocation is necessary to achieve a system that is conservative with respect to nutrients and positive on productivity. Adding organic matter to a site effectively constitutes fertilization; however, it is the labile fraction that is most sensitive to environmental change and variations in this fraction may have immediate impact on forest ecosystem productivity [21-23]. Accordingly, uptake potential and nutrient retention must be poised to accommodate net mineralization otherwise nutrients will be leached from the site. The interaction of altered biomass allocation and changes in soil fertility and moisture also need to be addressed since a sustained organic matter source is needed to build the SOM pool.

Forest management practices alter physical soil properties, and thereby affect SOM dynamics. The principal effect of a management practice is short-term when abiotic changes and soil disturbance occurs. However, except for cases of severe disturbance or wet soils, Johnson et al. [24] indicated harvesting does not have a deleterious effect on soil physical properties. Greater understanding of how harvesting, site preparation, and stand tending affect SOM processes is needed to prescribe systems that enhance $C$ retention on the site. Specific factors that need to be considered are changes in soil temperature, soil moisture, and physical structure. Fundamental questions regarding SOM development, retention, and ecosystem response need to be addressed. If successful, managing SOM through biomass incorporation could 
provide the basis for long-term gains in productivity and soil sustainability.

The objective of the study is to evaluate the feasibility of increasing SOM in a managed forest to enhance soil sustainability and $\mathrm{C}$ sequestration potential. We used biomass incorporation as a means to add organic matter to the soil and evaluated processes and mechanisms controlling organic matter turnover and storage.

\section{Methodology}

\subsection{Study site and treatments}

The study was located within the Savannah River Site National Environmental Research Park (US Department of Energy (DOE)-Savannah River Site) on the Atlantic Upper Coastal Plain. Two sites were selected that previously had been in cultivation and converted to a loblolly pine plantation in the early 1950s; the stand was harvested in August 1999. Each of the sites was prepared for planting by applying a mix of Garlon and Arsenal ${ }^{1}$ herbicides, and surface slash was spread evenly across the sites using a root rake. A total of $12,0.2$ ha plots, were laid out on each site, divided into four replicates and blocked according to soil series. Major soil series within treatment plots were classified according to USDA Soil Taxonomy [25] as Orangeburg (fine-loamy, kaolinitic, thermic Typic Kandiudults) and Dothan (fine-loamy, kaolinitic, thermic Plinthic Kandiudults) on the 'clay site' and Blanton (loamy, siliceous, semiactive, thermic, Grossarenic Paleudults) and Fuquay (loamy, kaolinitic, thermic, Arenic Plinthic Kandiudults) on the 'sandy site'. Soils within the 'clay site' were generally characterized by the presence of a shallow surface layer of $30 \mathrm{~cm}$ or less overlying an argillic horizon while the 'sandy site' consisted of a deep sandy surface layer ranging from 85 to $130 \mathrm{~cm}$ thickness overlying an argillic horizion. Within each block, plots were randomly assigned one of three treatments: (1) an unmodified control with native slash levels (1XNT), (2) native slash levels pulverized and

\footnotetext{
1 The use of trade names is for the convenience of the readers and does not imply an endorsement by the USDA Forest Service.
}

incorporated into the top $40 \mathrm{~cm}$ of soil surface (1XT), and (3) native slash supplemented with an equal amount of organic matter in the form of wood chips, pulverized and incorporated into the plots $(2 \mathrm{XT})$. To determine the amount of wood chips to be added to $2 X T$ plots, the amount of coarse-woody debris remaining on the surface following the logging operation was assessed for each plot using a line transect method [26]. Wood chips were obtained from power line clearing operations and contained leaves, branches and stems that were aged for several months prior to application. Chips were placed directly on plots by dump trucks, spread evenly throughout the plot with a loader, and pulverized and incorporated by a CMI RS500 reclaimer/stablizer (see footnote 1). This device pulverized coarse-woody debris and stumps and incorporated the organic matter to a depth of $40 \mathrm{~cm}$, effectively tilling the site during incorporation. Both sites were machine planted with loblolly pine at the beginning of 2000 and plots fertilized to offset the anticipated nutrient immobilization due to the incorporation of slash.

\subsection{Slash measurement}

Procedures by Brown [26] were followed for collecting slash data. Plot transects for treatment plots were established $15.2 \mathrm{~m}$ from the corner and installed parallel to the plot boundary. For blocks $1-6$ on the sandy site, plot transects were run in a north/south direction. For blocks 1-6 on the clay site plot transects were run in a northwest direction. Sampling transects $15.2 \mathrm{~m}$ in length were installed at 7.6, 15.2, $22.9,30.5,38.1,45.7$ and $53.4 \mathrm{~m}$ stations along the plot transect using a randomly selected azimuths of $0^{\circ}, 30^{\circ}, 60^{\circ}, 90^{\circ}, 120^{\circ}$, or $150^{\circ}$. Along each sampling transect, downed woody material that intersected each transect was tallied according to its size class. Size classes used were $0-0.6,0.6-2.54,2.54-7.62$, and $7.62+\mathrm{cm}$. Material in the $7.62+\mathrm{cm}$ class was noted as being sound or rotten and the diameter recorded. Three measurements of fuel depth were taken at points $0.30,0.61$, and $0.92 \mathrm{~m}$ from the origin of each transect. At 15.2 and $45.7 \mathrm{~m}$, a 0.02 ha fixed radius plot was installed to determine stump density. Stump diameter, along with height and species, were recorded for all stumps within the plot boundary. 


\subsection{Time-and motion study}

A time-and-motion study on the CMI RS 500B machine was performed during October 1999. The CMI was equipped with $28 \mathrm{~L}-26$ tires (20 ply rating), a $373 \mathrm{~kW} 3408$ V8 Caterpillar engine, and a rotating drum containing 268 teeth located at the center of the machine for grinding. Elements evaluated during the time study included lower drum, travel/mulch, raise drum, cut stump, and turn. Elemental definitions were as follows: Lower drum-time required to lower drum into the ground to begin mulching. The element started when downward motion of the drum was initialized and ended when forward motion of the tires began. Travel/mulch-all time spent by the machine traveling with the drum in the ground performing mulching. The element started with forward motion of the tires and ended when forward motion ceased. Raise drum - time required to raise the drum out of the ground. The element started when upward motion of the drum was initialized and ended when upward motion ceased. Cut stump-time required to cut through stumps large enough to interrupt machine travel. The element started when forward motion of the tires ceased and ended when a stump was mulched and forward motion was resumed. Turn-time required to turn the machine around to begin the next pass. The element started when the machine reached the end of a pass and forward motion of the tires ceased and ended when the machine was turned around and lowering of the drum resumed.

\subsection{Soil measurements}

Soil samples for chemical analysis were collected in $15 \mathrm{~cm}$ increments, with a $6 \mathrm{~cm}$ diameter soil corer, to a depth of $60 \mathrm{~cm}$ in each of the treatment plots. These samples were analyzed for cation exchange capacity (CEC), pH, and select soil nutrients ( $\mathrm{Mg}, \mathrm{K}, \mathrm{Ca}$ and P) using established techniques [27]. The soil samples were air dried and passed through a 2-mm sieve prior to analysis. Soil $\mathrm{pH}$ was determined on a volumetric basis by wetting $5 \mathrm{ml}$ soil subsamples with $5 \mathrm{ml}$ of deionized water and measuring the solution $\mathrm{pH}$. Soil nutrients were determined by placing $0.5 \mathrm{~g}$ soil subsamples into porcelain crucibles and then dry ashing the samples at $450^{\circ} \mathrm{C}$ for $4 \mathrm{~h}$. The samples were cooled in a closed furnace and then removed. To each ashed sample, $20 \mathrm{ml}$ of $20 \% \mathrm{HCl}$ was added. After an hour the sample was filtered through Whatman \#2 filter paper and the filtrate was analyzed for total nutrients on a Thermo Jarrell Ash 61E Inductively Coupled Plasma (ICP) spectrometer. The CEC was estimated from the available nutrient data determined by the Mehlich III extraction method. Soil subsamples $(1 \mathrm{ml})$ were extracted with $10 \mathrm{ml}$ of Mehlich III extracting solution and shaken for $5 \mathrm{~min}$. The subsamples were filtered into plastic tubes and analyzed for available nutrients by ICP spectrometry. Finally, $\mathrm{C}$ and $\mathrm{N}$ were measured by combustion analysis on a Carlo Erba N/A C/N/S (carbon/nitrogen/sulfur) analyzer.

Soil physical properties related to bulk density (BD) and gravimetric water content (GWC) were determined by the collection of soil cores approximately $60 \mathrm{~cm}$ in length and $5 \mathrm{~cm}$ in diameter from five 10 cations within each treatment plot. At each sampling location within a plot, soil cores were removed from two points: within the bed (IB) and from inter row (IR) locations approximately $1 \mathrm{~m}$ off each bed. Each core was subdivided into $10 \mathrm{~cm}$ increments, dried in a force-vent oven at $105^{\circ} \mathrm{C}$ for $36 \mathrm{~h}$ and dry weights recorded for each sample [28]. Particle size analysis was performed by the pipette method [29]. Soil strength measurements were conducted in situ on nine treatments plots (replications 1-3) by the insertion of a Rimik CP20 cone penetrometer to a depth of $50 \mathrm{~cm}$ and the data recorded in $2.5 \mathrm{~cm}$ increments; final data is expressed as cone index values in units of pressure (MPa) and averaged for each $10 \mathrm{~cm}$ of depth [30].

Soil physical property data presented in this paper are limited to the 'sandy site'; sampling of the "clay site' was scheduled for a later time when soil conditions were more conducive for sampling.

\subsection{Statistical analysis}

Treatment differences for soil $\mathrm{C}, \mathrm{N}$, nutrients, bulk density, gravimetric water content and cone index were determined by analysis of variance (ANOVA) using SAS statistical software (SAS Institute, Cary, NC). In each of the statistical comparisons, each sampling depth increment was treated separately and there were no comparisons among depth increments. Additionally, each site was treated separately and no statistical comparisons were made between sites. 
Table 1

Mean stump and slash data for the CMI RS500 B by site

\begin{tabular}{|c|c|c|c|c|c|c|}
\hline \multirow[t]{2}{*}{ Slash level } & \multicolumn{3}{|l|}{ Sandy site } & \multicolumn{3}{|l|}{ Clay site } \\
\hline & Stumps/ha & $\begin{array}{l}\text { Stump diameter } \\
(\mathrm{cm})\end{array}$ & Tonnes/ha & Stumps/ & $\begin{array}{l}\text { Stump diameter } \\
(\mathrm{cm})\end{array}$ & Tonnes/ha \\
\hline $1 \mathrm{XT}$ & 321 & 35.8 & 37.61 & 309 & 33.8 & 32.24 \\
\hline $2 \mathrm{XT}$ & 297 & 40.6 & 102.30 & 346 & 37.3 & 33.64 \\
\hline
\end{tabular}

Table 2

Mean elemental time summary for the CMI RS500 B operating in 1.14 ha plots

\begin{tabular}{|c|c|c|c|c|c|c|c|c|c|c|}
\hline \multirow[t]{2}{*}{ Slash level } & \multicolumn{5}{|c|}{ Sandy site } & \multicolumn{5}{|c|}{ Clay site } \\
\hline & $\begin{array}{l}\text { Travel } \\
\text { (min) }\end{array}$ & $\begin{array}{l}\text { Cut } \\
\text { (min) }\end{array}$ & $\begin{array}{l}\text { Raise/ } \\
\text { lower } \\
\text { (min) }\end{array}$ & $\begin{array}{l}\text { Turn } \\
\text { (min) }\end{array}$ & $\begin{array}{l}\text { Total } \\
\text { (min) }\end{array}$ & $\begin{array}{l}\text { Travel } \\
\text { (min) }\end{array}$ & $\begin{array}{l}\text { Cut } \\
\text { (min) }\end{array}$ & $\begin{array}{l}\text { Raise/ } \\
\text { lower } \\
\text { (min) }\end{array}$ & $\begin{array}{l}\text { Turn } \\
(\mathrm{min})\end{array}$ & $\begin{array}{l}\text { Total } \\
\text { (min) }\end{array}$ \\
\hline $1 \mathrm{XT}$ & 42.01 & 16.73 & 10.40 & 25.29 & 94.43 & 44.02 & 6.34 & 15.00 & 22.68 & 88.04 \\
\hline $2 \mathrm{XT}$ & 42.94 & 19.58 & 7.81 & 24.38 & 94.72 & 38.52 & 6.16 & 11.36 & 23.34 & 79.39 \\
\hline
\end{tabular}

\section{Results and discussion}

\subsection{Slash measurement}

Table 1 is a summary of the site characteristics in terms of stump density, stump diameter, and slash level. Due to a much lighter slash level on the clay site, 2XT was only about one-third of that for the sandy site. Since each site was examined independently as to the effects of different slash loads on soil properties, it was not necessary that each site have the same slash load.

\subsection{Time-and-motion study}

Table 2 summarizes the time study elements for the CMI. Mean travel time on the sandy site was almost identical between slash levels. Mean cut time on the sandy site was nearly 3 min longer for $2 \mathrm{XT}$. This is most likely due to a larger pine stump diameter, which averaged $35.8 \mathrm{~cm}$ for $1 \mathrm{XT}$ and $40.6 \mathrm{~cm}$ for 2XT. Travel times were almost the same between both slash levels on the sandy site, occupying $45 \%$ of the total productive time. Travel times for $1 \mathrm{XT}$ and $2 \mathrm{XT}$ on the clay site occupied $50 \%$ and $49 \%$ of the total productive time, respectively. Larger stump diameters and higher slash levels on the sandy site resulted in longer cut times as compared to the clay site. On the sandy site, time spent cutting was about $18 \%$ of the total time for $1 \mathrm{XT}$ and $21 \%$ for $2 \mathrm{XT}$. On the clay site, cut time accounted for only about $7 \%$ of the total time for both slash levels. Time spent raising and lowering the cutting drum was lower for the sandy site, occupying $11 \%$ and $8 \%$ of the total time for $1 \mathrm{XT}$ and $2 \mathrm{XT}$, respectively. For the clay site raising and lowering the drum accounted for $17 \%$ of the total time for $1 \mathrm{XT}$ and $14 \%$ for $2 \mathrm{XT}$. Turn time was fairly constant for each site/treatment combination and ranged from $26 \%$ to $29 \%$.

Production and costs associated with implementing these treatments using the CMI machine are summarized in Table 3 . A rental rate of \$US350 $\mathrm{SMH}^{-1}$ (Scheduled Machine Hour) was used for calculating costs. Labor rate was based on Davis-Bacon Wage Determination for Aiken County, South Carolina, Group 2 power equipment operator, plus $5.91 \%$ benefits. Mean travel, cut, raise, lower and turn times were determined for each site/treatment combination and used to estimate production and cost of the machine operating on a square 8-ha tract. Production rates ranged from 0.65 to 0.79 ha $\mathrm{PMH}^{-1}$ (Productive Machine Hour), with 
Table 3

Production and cost summary for the CMI RS $500 \mathrm{~B}$

\begin{tabular}{|c|c|c|c|c|c|c|}
\hline Slash level & \multicolumn{3}{|l|}{ Sandy site } & \multicolumn{3}{|l|}{ Clay site } \\
\hline $2 \mathrm{XT}$ & 350 & 0.67 & 614.57 & 350 & 0.79 & 521.22 \\
\hline
\end{tabular}

${ }^{a}$ Scheduled Machine Hours.

bProductivity based on a travel distance of $284 \mathrm{~m}$.

cProductive Machine Hours.

${ }^{d}$ Cost based on rental rate of $\$ 350$ per $\mathrm{SMH}$ and a utilization rate of $85 \%$.

Table 4

Delay summary for both sites and slash levels

\begin{tabular}{lc}
\hline & Time (min) \\
\hline Productive & \\
Backing-up & 4.86 \\
Misc. travel & 51.38 \\
Total & 56.24 \\
& \\
Non-productive & \\
Stuck & 70.04 \\
Repair hose & 9.87 \\
Stump hung in drum & 53.28 \\
Stalled cutting stump & 1.61 \\
Check engine & 0.46 \\
Lunch & 46.74 \\
Other & 18.98 \\
Total & 200.98 \\
& \\
Total & 257.22 \\
\hline
\end{tabular}

the lowest occurring for $1 \mathrm{XT}$ on the sandy site and the highest occurring for $2 \mathrm{XT}$ on the clay site. Costs ranged from \$US 521 to $633 \mathrm{ha}^{-1}$. Compared to a typical chemical site preparation cost of about \$US $247 \mathrm{ha}^{-1}$ and a mechanical site preparation cost of about \$US $370 \mathrm{ha}^{-1}$ [31], use of the CMI for this intense site preparation may not be feasible.

Productive and non-productive delays observed during the study are summarized in Table 4. All delays accounted for $4.29 \mathrm{~h}$ during the study period. The CMI spent a total of 23.77 PMH treating plots during the study period. Summing productive time and delay time resulted in a scheduled operating time of $28.06 \mathrm{~h}$. Dividing productive time by scheduled operating time translated into a utilization rate of $85 \%$.

\subsection{Soil carbon and nitrogen}

Soil $\mathrm{C}$ and $\mathrm{N}$ concentrations to a depth of $60 \mathrm{~cm}$, $1.5 \mathrm{yr}$ after treatment installation, are shown for the sandy and clay sites (Table 5). The largest $\mathrm{C}$ increases were on the sandy site at the $15-30 \mathrm{~cm}$ depth where the 1XT and 2XT treatments were $183 \%$ and $265 \%$ higher, respectively, than the $1 \mathrm{XNT}$ treatment. Soil N increases (as compared to the $1 \mathrm{XNT}$ treatment) were $170 \%$ and $220 \%$ at the $15-30 \mathrm{~cm}$ depth for the IXT and $2 X T$ treatments, respectively. On the clay sites, soil $\mathrm{C}$ increased (as compared to the 1XNT treatment) $171 \%$ and $188 \%$ for the $1 \mathrm{XT}$ and $2 \mathrm{XT}$ treatments at the $15-30 \mathrm{~cm}$ depth. Soil $N$ increased $86 \%$ and $100 \%$ for the 1XT and 2XT treatments at the $15-30 \mathrm{~cm}$ depth. Additionally, soil C increased $100 \%$ and $131 \%$ for the 1XT and 2XT treatments at the $30-45 \mathrm{~cm}$ depth at the clay site.

Generally, for each site and depth increment, soil C and $\mathrm{N}$ concentrations were greatest for the tillage treatments (1XT and 2XT) as compared with the non-tilled treatment (1XNT). However, the increases were usually only significant (at the $p>0.05$ level) in the 15 $-30 \mathrm{~cm}$ depth increment. This observation may be partially explained by the effectiveness of the CMI RS500 reclaimer/stablizer to mix in the slash material resulting in a larger amount of slash material being concentrated in the $15-30 \mathrm{~cm}$ depth increment. Additionally, tillage effects on soil temperature and soil moisture are possible which can, in turn, influence soil microbial activity and, ultimately, SOM decomposition. However, this effect was not examined in this study. Evidence of accelerated SOM decomposition at the $15-30 \mathrm{~cm}$ depth increment at the sandy site is presented in Table 6. At this depth increment, both CEC 
Table 5

Carbon $\left(\mathrm{g} \mathrm{kg}^{-1}\right)$ and Nitrogen $\left(\mathrm{g} \mathrm{kg}^{-1}\right)$ content of two sites amended with two levels of slash (1XT and 2XT) compared to an unamended site (1XNT) $1.5 \mathrm{yr}$ after incorporation, South Carolina

\begin{tabular}{|c|c|c|c|c|}
\hline \multirow[t]{2}{*}{ Depth (m) } & \multicolumn{2}{|l|}{ Sandy site } & \multicolumn{2}{|l|}{ Clay site } \\
\hline & Carbon $( \pm \mathrm{SE})$ & Nitrogen $( \pm \mathrm{SE})$ & Carbon (土SE) & Nitrogen $( \pm S E)$ \\
\hline \multicolumn{5}{|l|}{$1 \mathrm{XNT}$} \\
\hline $0.0-0.15$ & $0.93 \pm 0.28$ & $0.02 \pm 0.01$ & $0.80 \pm 0.17$ & $0.02 \pm 0.01$ \\
\hline $0.15-0.30$ & $0.31 \pm 0.09$ & $0.01 \pm 0.00$ & $0.17 \pm 0.04$ & $0.01 \pm 0.00$ \\
\hline $0.30-0.45$ & $0.18 \pm 0.07$ & $0.01 \pm 0.00$ & $0.13 \pm 0.02$ & $0.01 \pm 0.00$ \\
\hline $0.45-0.60$ & $0.13 \pm 0.04$ & $0.01 \pm 0.00$ & $0.23 \pm 0.07$ & $0.01 \pm 0.00$ \\
\hline \multicolumn{5}{|l|}{$1 \mathrm{XT}$} \\
\hline $0.0-0.15$ & $1.23 \pm 0.51$ & $0.03 \pm 0.01$ & $0.64 \pm 0.20$ & $0.02 \pm 0.01$ \\
\hline $0.15-0.30$ & $0.88 \pm 0.23$ & $0.03 \pm 0.01$ & $0.46 \pm 0.08$ & $0.01 \pm 0.00$ \\
\hline $0.30-0.45$ & $0.29 \pm 0.08$ & $0.01 \pm 0.00$ & $0.26 \pm 0.04$ & $0.01 \pm 0.00$ \\
\hline $0.45-0.60$ & $0.10 \pm 0.04$ & $0.01 \pm 0.00$ & $0.12 \pm 0.02$ & $0.01 \pm 0.00$ \\
\hline \multicolumn{5}{|l|}{$2 \mathrm{XT}$} \\
\hline $0.0-0.15$ & $0.94 \pm 0.21$ & $0.02 \pm 0.00$ & $0.65 \pm 0.09$ & $0.02 \pm 0.00$ \\
\hline $0.15-0.30$ & $1.13 \pm 0.32$ & $0.03 \pm 0.01$ & $0.49 \pm 0.16$ & $0.01 \pm 0.00$ \\
\hline $0.30-0.45$ & $0.31 \pm 0.07$ & $0.01 \pm 0.00$ & $0.30 \pm 0.12$ & $0.01 \pm 0.00$ \\
\hline $0.45-0.60$ & $0.09 \pm 0.02$ & $0.01 \pm 0.00$ & $0.36 \pm 0.24$ & $0.01 \pm 0.00$ \\
\hline
\end{tabular}

Table 6

Cation Exchange Capacity (CEC) and pH of two sites amended with two levels of slash (IXT and 2XT) compared to an unamended (1XNT) site approximately $1.5 \mathrm{yr}$ after installation, South Carolina

\begin{tabular}{|c|c|c|c|c|c|c|}
\hline \multirow[t]{2}{*}{ Depth (m) } & \multicolumn{3}{|l|}{ CEC } & \multicolumn{3}{|l|}{$\mathrm{pH}$} \\
\hline & $1 \mathrm{XNT}$ & $1 X T$ & $2 \mathrm{XT}$ & $1 \mathrm{XNT}$ & IXT & $2 \mathrm{XT}$ \\
\hline \multicolumn{7}{|l|}{ Clay site } \\
\hline $0.0-0.15$ & 3.02 & 2.13 & 2.95 & 4.95 & 5.07 & 5.15 \\
\hline $0.15-0.30$ & 1.40 & 2.40 & 1.63 & 5.10 & 5.08 & 5.15 \\
\hline $0.30-0.45$ & 1.60 & 1.88 & 1.88 & 5.30 & 5.25 & 5.35 \\
\hline $0.45-0.60$ & 1.63 & 2.42 & 2.48 & $5.20 \mathrm{a}$ & $5.38 b$ & $5.50 \mathrm{~b}$ \\
\hline \multicolumn{7}{|l|}{ Sandy site } \\
\hline $0.0-0.15$ & 4.67 & 7.07 & 7.58 & 4.58 & 4.88 & 4.73 \\
\hline $0.15-0.30$ & $2.10 \mathrm{a}^{\mathrm{a}}$ & $5.85 b$ & $8.55 \mathrm{~b}$ & $4.55 \mathrm{a}$ & $4.83 b$ & $4.78 \mathrm{~b}$ \\
\hline $0.30-0.45$ & 1.58 & 2.52 & 3.15 & 4.75 & 4.95 & 4.75 \\
\hline $0.45-0.60$ & 2.47 & 1.65 & 1.33 & 4.80 & 4.95 & 4.88 \\
\hline
\end{tabular}

${ }^{a}$ For a given measurement and depth increment (i.e., across half a row), values followed by different letters are significantly different at the $p>0.05$ level; significant differences were detected only for depth indicated in table.

and $\mathrm{pH}$ increased in the tilled (1XT and $2 \mathrm{XT}$ ) plots as compared to the non-tilled plot (1XNT); however, these increases were only significant for the CEC increase $(p=0.02)$. This effect was not seen on the clay site and may be due to the stabilizing effect of clay [16].
Slash loading had a minimal effect on soil $\mathrm{C}$ and $\mathrm{N}$ concentrations. Although the $2 \mathrm{XT}$ treatment plots generally had higher soil $\mathrm{C}$ and $\mathrm{N}$ concentrations, as compared to the 1XT treatment plots, for both sites and at all depths, the effect was not statistically significant at the $p>0.05$ level. It is probably too 
Table 7

Calcium $\left(\mathrm{kg} \mathrm{ha}^{-1}\right)$ and Magnesium $\left(\mathrm{kg} \mathrm{ha}^{-1}\right)$ content of two sites amended with two levels of slash (1XT and 2XT) compared to an unamended site (IXNT) 1.5 yr after application, South Carolina

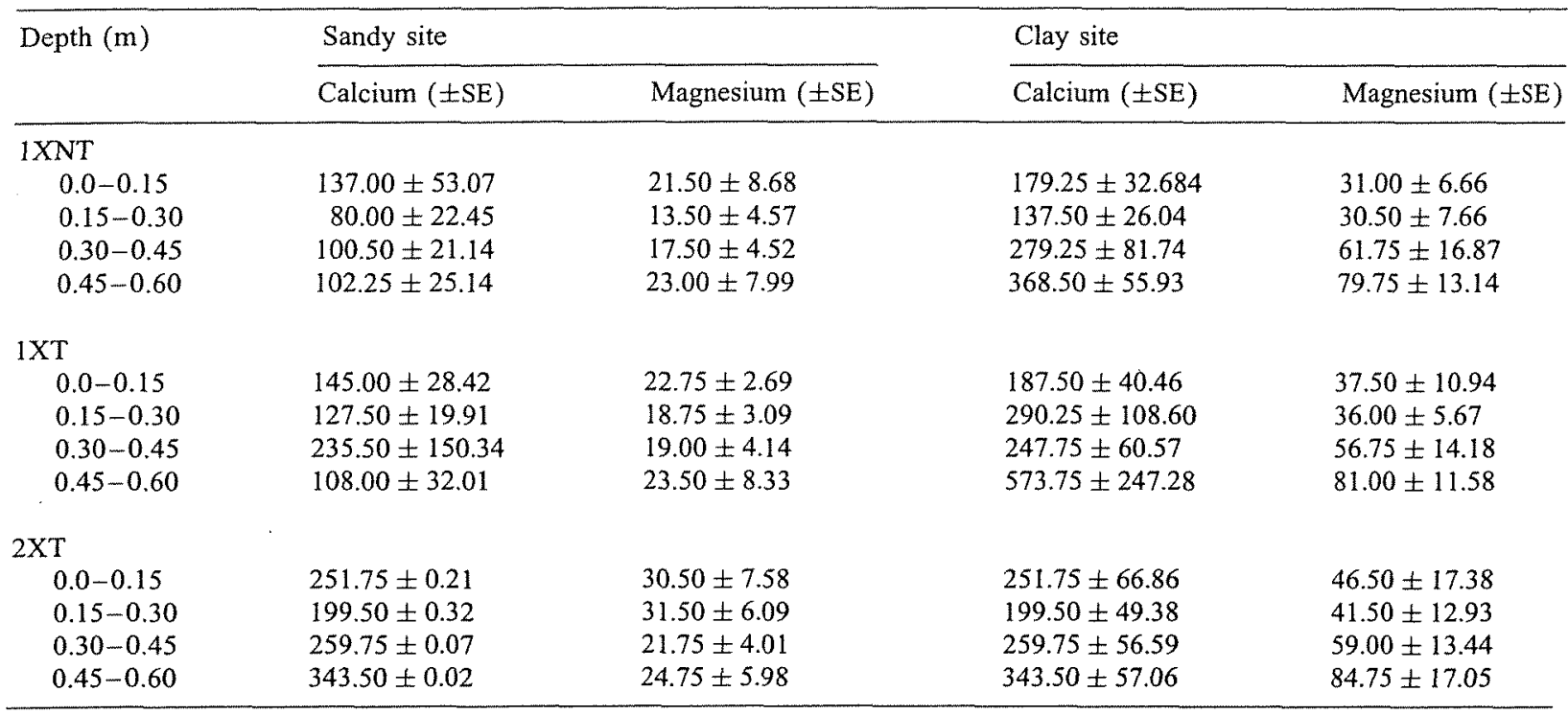

early in the study to detect significant effects on decomposition and organic matter stabilization due to slash load and soil texture. Any effects of slash loading and soil texture may be manifested in the upcoming years as the sites reach a steady state in regards to microbial populations and activity.

\subsection{Soil nutrients}

At $1.5 \mathrm{yr}$ after treatment installation, soil nutrient contents were not significantly different (at the $p>0.05$ level) at any depth in the clay site (Tables 7 and 8 ). However, at the sandy site (at the $15-30 \mathrm{~cm}$ depth) Ca content was significantly higher in the $2 \mathrm{XT}$ treatment while $\mathrm{Mg}$ content slightly exceeded the $5 \%$ level of significance ( $p=0.02$ and 0.06 , respectively) as compared to the 1XT or 1XNT treatments. Treatments 1XT and 1XNT were not significantly different from each other ( $p=0.16$ and 0.39 , respectively) (Table 7). There was considerable variability in the soil $\mathrm{K}$ for both sites (Table 8 ) and as a result, soil $\mathrm{K}$ was not significantly different (at the $p>0.05$ level) at any of the depths measured in either site. This variability is not surprising since $\mathrm{K}$ is a very mobile nutrient and is quickly released from decomposing plant tissue [32]. In the sandy site, soil $\mathrm{P}$ contents for the 2XT and 1XT treatments were generally higher than the 1XNT treatment in subsurface layers; however, this effect was only significant for the $2 \mathrm{XT}$ treatment at the $15-30 \mathrm{~cm}$ depth $(p=0.04)$ (Table 8$)$. No significant differences in soil $\mathrm{P}$ contents were observed at any depth at the clay site. Plant tissue contains a pool of $\mathrm{P}$ that is generally not released by methods other than decomposition (i.e., solubilization and leaching) [32]. The observation that significant inputs of $P$ from incorporated slash were being realized on the sandy sites and not the clay sites suggests that decomposition is proceeding at a faster rate at the sandy site.

\subsection{Soil physical properties-sandy site}

Soil textural analyses indicated the upper $30 \mathrm{~cm}$ of the 'sandy' site to be composed of approximately $90 \%$ (or more) sand and less than 10\% clay and silt; clay and silt contents increased to $18 \%$ and $23 \%$, respectively, in the $30-45$ and $45-60 \mathrm{~cm}$ depth range, but sand content remained greater than $75 \%$ in soil layers to a depth of $60 \mathrm{~cm}$. Soil textural classifications of the $0-30$ and $30-60 \mathrm{~cm}$ soil layers were determined to be sand and sandy loam, respectively. 
Table 8

Potassium $\left(\mathrm{kgha}^{-1}\right)$ and Phosphorus $\left(\mathrm{kg} \mathrm{ha}^{-1}\right)$ content of two sites amended with two levels of slash (IXT and 2XT) compared to an unamended site (1XNT) $1.5 \mathrm{yr}$ after installation, South Carolina

\begin{tabular}{|c|c|c|c|c|}
\hline \multirow[t]{2}{*}{ Depth (m) } & \multicolumn{2}{|l|}{ Sandy site } & \multicolumn{2}{|l|}{ Clay site } \\
\hline & Potassium $( \pm \mathrm{SE})$ & Phosphorus ( $\pm S E$ ) & Potassium $( \pm \mathrm{SE})$ & Phosphorus ( $\pm \mathrm{SE}$ ) \\
\hline \multicolumn{5}{|l|}{$1 \mathrm{XNT}$} \\
\hline $0.0-0.15$ & $32.75 \pm 9.23$ & $75.00 \pm 10.40$ & $27.00 \pm 16.59$ & $49.75 \pm 11.19$ \\
\hline $0.15-0.30$ & $26.25 \pm 9.64$ & $30.75 \pm 8.13$ & $32.25 \pm 18.04$ & $22.75 \pm 9.04$ \\
\hline $0.30-0.45$ & $29.25 \pm 17.09$ & $13.00 \pm 3.42$ & $38.50 \pm 13.17$ & $7.25 \pm 3.04$ \\
\hline $0.45-0.60$ & $24.00 \pm 11.35$ & $6.75 \pm 1.03$ & $30.75 \pm 10.49$ & $4.00 \pm 1.35$ \\
\hline \multicolumn{5}{|l|}{$1 \mathrm{XT}$} \\
\hline $0.0-0.15$ & $27.25 \pm 6.60$ & $74.00 \pm 20.14$ & $26.25 \pm 7.82$ & $29.00 \pm 8.13$ \\
\hline $0.15-0.30$ & $26.75 \pm 6.41$ & $61.50 \pm 16.84$ & $35.00 \pm 4.92$ & $28.25 \pm 8.53$ \\
\hline $0.30-0.45$ & $18.25 \pm 0.85$ & $25.00 \pm 4.04$ & $24.50 \pm 15.25$ & $14.25 \pm 4.78$ \\
\hline $0.45-0.60$ & $31.00 \pm 6.65$ & $9.75 \pm 0.85$ & $30.75 \pm 11.15$ & $4.25 \pm 1.38$ \\
\hline \multicolumn{5}{|l|}{$2 \mathrm{XT}$} \\
\hline $0.0-0.15$ & $33.00 \pm 16.95$ & $61.00 \pm 12.56$ & $23.00 \pm 10.76$ & $31.25 \pm 0.94$ \\
\hline $0.15-0.30$ & $37.00 \pm 15.85$ & $60.75 \pm 8.85$ & $19.75 \pm 13.28$ & $29.75 \pm 10.09$ \\
\hline $0.30-0.45$ & $36.75 \pm 7.30$ & $23.75 \pm 5.51$ & $41.25 \pm 9.23$ & $12.00 \pm 5.15$ \\
\hline $0.45-0.60$ & $36.75 \pm 1.80$ & $9.75 \pm 1.03$ & $32.25 \pm 8.87$ & $5.25 \pm 1.55$ \\
\hline
\end{tabular}

Mean bulk density (BD) values were consistently higher in 1XNT to a depth of $40 \mathrm{~cm}$ compared to the tilled treatments (Table 9). The BD values detected in $1 \mathrm{XNT}$ were the result of previous harvest activity, the movement of slash material within the treatment area and the impact of machine planting operations. The implementation of tillage treatments decreased $\mathrm{BD}$ in both 1XT and 2XT to the depth of $40 \mathrm{~cm}$ as a result of the incorporation of slash materials; additional trafficking may have contributed to higher $\mathrm{BD}$ below the $40 \mathrm{~cm}$ depth. A reduction in $\mathrm{BD}$ would be expected in 1XT and 2XT throughout the upper $40 \mathrm{~cm}$ of the soil profile that was equivalent to the depth of tillage. An elevated BD level underlain by soil layers with lower $B D$ values indicated the presence of tillage pans at depths of $20 \mathrm{~cm}$ in $1 X N T$ and $50 \mathrm{~cm}$ in tilled plots. Slight differences in mean BD were detected between tilled treatments (1XT and 2XT) that varied by depth. Statistical differences among treatments were detected at two depths: $20-30$ and $50-60 \mathrm{~cm}$ with $1 \mathrm{XNT}$ significantly different from tilled treatments; no significant differences were detected between tilled treatments.

Gravimetric water content (GMC) was higher in the untilled treatment presumably due to pore structure that favored the infiltration and retention of soil moisture (Table 9). Differences were noted between the tilled treatments in water content with higher moisture content noted in 2XT compared to 1XT at all depth increments. Although differences were observed in GMC among all treatments, significant differences were detected between IXNT and 1XT in the 40$50 \mathrm{~cm}$ depth range while $2 \mathrm{XT}$ was not significantly different from either treatment.

Soil strength was greatest in the 1XNT treatment with a slight decrease noted in the $40-50 \mathrm{~cm}$ soil layer. Implementation of tillage treatments decreased soil strength at all comparable depths compared to $1 \mathrm{XNT}$ and but resulted in higher cone index values in 2XT than 1XT. Significant differences were detected more consistently in cone index measurements with the cone index values of IXNT significantly different from 1XT at all depth increments except the 40 $-50 \mathrm{~cm}$ depth. Significant differences in cone index measurements between 1XNT and 2XT were detected at only two depths: $10-20$ and $20-30 \mathrm{~cm}$. No differences were detected between tilled treatments at any depth (Table 9).

Differences in the means of soil physical variables were detected by position and contributed to differences in means of soil physical properties (Table 9). 
Table 9

Treatment means and means of samples from in bed (IB) and inter-row (IR) locations for bulk density (BD) $\left(\mathrm{Mg} \mathrm{m}^{-3}\right), \mathrm{gravimetric}^{-3}$ water content (GMC) (\%), and cone index (CI) (MPa) of the sandy site amended with two levels of slash (IXT and 2XT) compared to an unamended site (1XNT) $1.5 \mathrm{yr}$ after installation, South Carolina

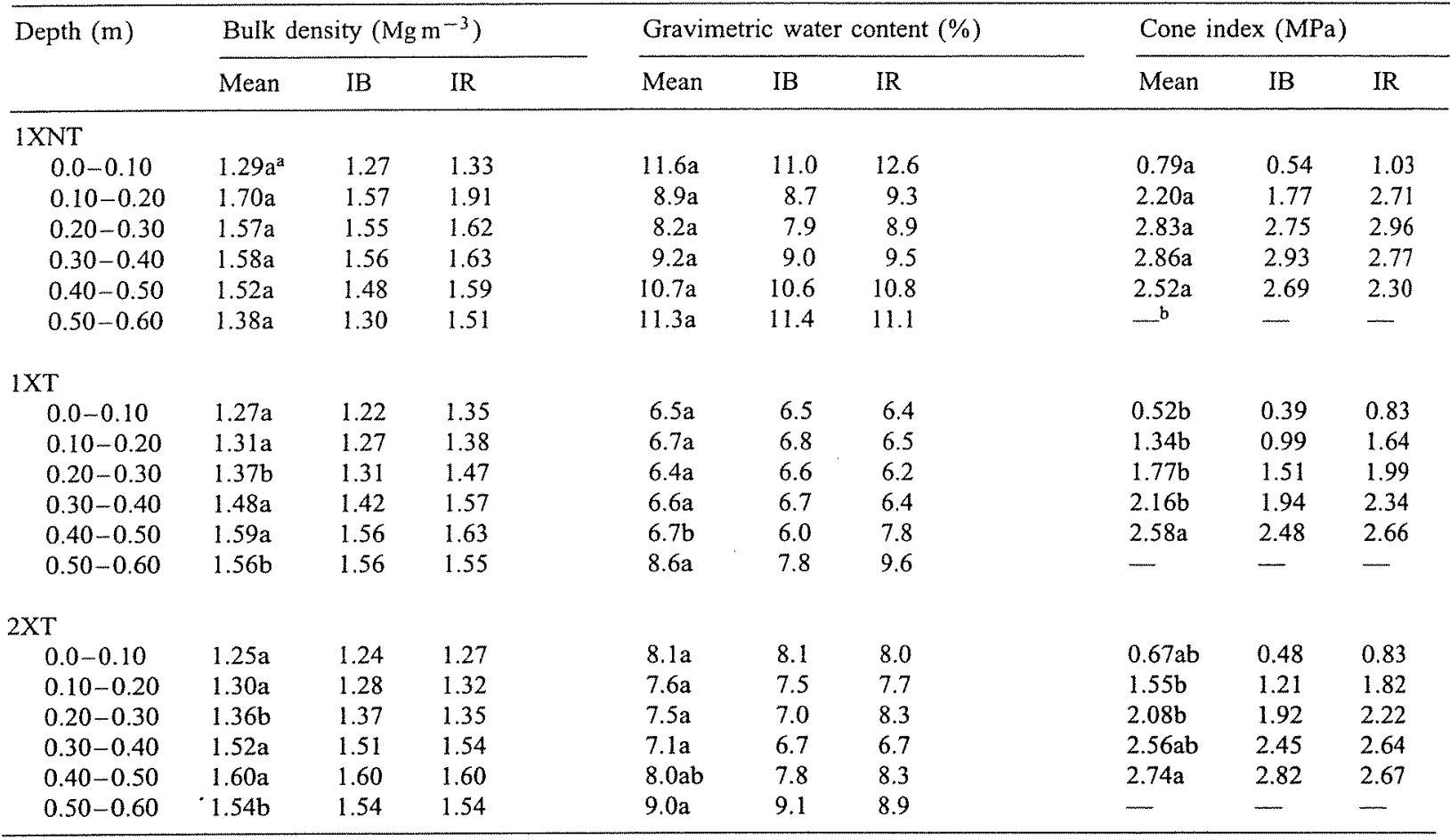

${ }^{a}$ Means are compared among treatments by depth down the mean column for each soil property; means with similar letters are not significantly different at the $p<0.05$ level. No comparisons were made between IB and IR values.

${ }^{b}$ Cone index values were collected to a depth of $0.50 \mathrm{~m}$.

Bulk density was consistently lower in samples collected from in bed positions compared to inter-row positions in all treatments; this would be expected as a result of biomass incorporation and tillage operations. Bulk density was consistently higher in 1XNT compared to tilled treatments at comparable depth and position. Bulk density levels in beds of 1 XT were lower compared to $2 \mathrm{XT}$ but the reverse was observed for inter-row BD of tilled treatments. Slight differences in response between sampling positions in $2 \mathrm{XT}$ may be due to the influence of additional organic matter additions on BD.

Soil moisture was consistently higher in 1 XNT than tilled treatments at comparable position and depths while soil moisture levels in 2XT generally exceeded levels in IXT when compared by position and depth.
Cone index (CI) values were consistently lower in the beds compared to inter-row areas in each treatment in the upper $40 \mathrm{~cm}$; CI values were consistently higher in IXNT at comparable position and depth in the upper $40 \mathrm{~cm}$ than tilled treatments. Soil strength response in tilled treatments was similar to previous results in that cone index values of IB were lower in IXT than 2XT but differed in that inter-row levels in $2 X T$ were higher than $1 X T$. The overall difference between sampling position was less pronounced in $2 \mathrm{XT}$ than 1XT suggesting more uniform soil conditions.

Soil physical data suggested compaction was present in the harvested/unamended site as indicated by $\mathrm{BD}$ and $\mathrm{CI}$ values of $1.70 \mathrm{Mg} \mathrm{m}^{-3}$ and $2.96 \mathrm{MPa}$, respectively, in the upper $30 \mathrm{~cm}$. Maximum bulk density values between 1.7 and $2.1 \mathrm{Mg} \mathrm{m}^{-3}$ were reported 
for soils with sand contents between $73 \%$ and $97 \%$ [33]. The authors noted the percentage of coarse sand had a significant effect on the final BD and lowered the critical soil moisture content at which maximum compaction was likely to occur. This was supported by results reported by Panayiotopoulos and Mullins [34] who measured $\mathrm{BD}$ values that ranged between 1.55 and $1.90 \mathrm{Mg} \mathrm{m}^{-3}$ when course sand was compacted under relatively dry soil conditions. The maximum potential for the sandy soil to be compacted may be indicated by $\mathrm{BD}$ levels of $1.91 \mathrm{Mg} \mathrm{m}^{-3}$ of inter-row areas of 1XNT. The degree of compaction that was measured in the 1XNT treatment was consistent with previously reported values for sandy soils. Ayers and Perumpral [35] reported CI values that exceeded $2.5 \mathrm{MPa}$ as sand content increased in laboratory tests evaluating the relationship between $\mathrm{CI}$ and soil texture; they further demonstrated maximum $\mathrm{CI}$ values at lower soil moisture content in soils with sandier textures.

The incorporation of organic materials produced a tillage effect to a depth of $40 \mathrm{~cm}$ that resulted in reductions of $\mathrm{BD}$ and $\mathrm{CI}$ in beds and in inter-rows compared to IXNT. Below the depth of incorporation, $\mathrm{BD}$ and $\mathrm{CI}$ of amended treatments exceeded the control treatment that may have been the result of the additional trafficking related to surface distribution and incorporation of organic matter. It is apparent that $\mathrm{BD}$ and $\mathrm{CI}$ responded positively to deep incorporation of organic materials with reductions in $\mathrm{BD}$ and $\mathrm{CI}$ to levels that would not be expected to limit root proliferation [36]. This was especially important in order to reduce the degree of compaction that was evident in the $10-20 \mathrm{~cm}$ layer of $1 \mathrm{XNT}$. Although slight differences in soil physical response were detected between the amended plots, the incorporation of additional organic matter (2XT) appeared to result in lower BD but elevated soil strength in both sampling locations compared to $1 \mathrm{XT}$. The degree of trafficking necessary to install the $2 \mathrm{XT}$ treatment may have contributed to the degree of compaction and its transmission to deeper parts of a soil profile [37]. The degree of compaction may have been attenuated by the presence of organic matter through its influence on soil compactibility and an increase in water content at which maximum compaction can occur [38]. The final response of soil strength may be due less to the overall impact of trafficking but rather the interaction of soil texture and soil moisture. Ayers and Perumpral [35] indicated that a slight increase in BD was observed when a sandy textured soil was compacted under low soil moisture conditions but resulted in an exponential increase in soil strength.

\section{Conclusions}

\subsection{Time-and-motion study}

Study results indicated that using a machine such as the CMI has potential for site preparation where increasing soil $\mathrm{C}$ and nutrients is a priority. Though cost estimates derived from the study indicate that the operations would not be feasible compared to traditional site preparation methods, an increase in production and utilization could reduce treatment costs significantly, making it a viable option.

\subsection{Soil chemical properties}

The results of this study indicate that incorporating forest slash during site preparation is an effective means of increasing soil $\mathrm{C}$ and nutrients. The effects of soil texture, tillage and slash load on soil $C$ and nutrient levels were examined and were found to be variable in their influence. Soil textural characteristics may have impacted decomposition and inputs of $\mathrm{C}$ and nutrients through organic material additions detected in this study may have been more rapidly released in coarse textured soils. Although the fine textured soils had lower rates of decomposition for the incorporated slash, there may be more stabilization of the decomposed material; however, this effect has not yet been detected in this study. Generally, plots with higher slash loads (2XT) had higher levels of $\mathrm{C}$ and nutrients but these increases were not significantly different from the lower slash level (1XT). These differences may become significant with time as the sites reach a steady state in regards to microbial populations and activities.

\subsection{Soil physical properties}

Harvesting activities may have contributed to high levels of soil compaction as evidenced by soil physical status in IXNT especially in the immediate 
subsurface layer. Incorporation of biomass materials reduced compaction in beds and inter-row areas possibly due to tillage activities associated with the addition of partially decomposed organic materials. Soil bulk density levels indicated that the addition of incorporated materials had a positive impact especially in the double addition of mulch. However, cone index levels for the highest addition of organic materials showed an increase in compaction.

\section{References}

[1] Houghton R, Hobbie J, Melillo J. Changes in the carbon content of terrestrial biota and soils between 1860 and 1980: a net release of $\mathrm{CO}_{2}$ to the atmosphere. Ecological Monographs $1983 ; 53: 235-62$.

[2] Richter DD, Markewitz D, Trumbore SE, Wells CG. Rapid accumulation and tumover of soil carbon in a re-establishing forest. Nature 1999;400:56-8.

[3] Barber BL, Van Lear DH. Weight loss and nutrient dynamics in decomposing woody loblolly pine logging slash. Soil Science Society America Journal 1984;48:906-10.

[4] Van Lear DH, Kapeluck PR, Parker MM. Distribution of carbon in a Piedmont soil as affected by loblolly pine management. In: McFee WW, Kelly JM, editors. Carbon forms and functions in forest soils. Madison, WI: American Society of Agronomy, 1991. p. 594.

[5] Tiarks A, Klepzig K, Sanchez F, Lih M, Powell J, Buford $M$. Roles of coarse woody debris in the loblolly pine ecosystem. In: Haywood JD, editor. Proceedings of the 10th Biennial Southern Silviculture Research Conference. General Technical Report SRS-30. United States Department of Agriculture-Forest Service, Southern Research Station, Asheville, NC, 1999. p. 238-42.

[6] Richter DD, Markewitz D, Wells CG, Allen HL, Dunscome JK, Harrison K, Heine PR, Stuanes A, Urrego B, Bonani G. Carbon cycling in a loblolly pine forest: implication for the missing sink and for the concept of soil. In: McFee WW, Kelly JM, editors. Carbon forms and functions in forest soils. Madison, WI: American Society of Agronomy, 1991. p. 594.

[7] Buford M, Stokes BJ, Sanchez FG, Carter EA. Using biomass to improve site quality and carbon sequestration. In: Lowe AT, Smith CT, editors. Proceedings of the IEA Bioenergy Task 18 Workshop and Joint Workshop with Task 25, Developing System for Integrating Bioenergy into Environmentally Sustainable Forestry. Forest Research Bulletin Number 21. New Zealand Forest Research Institute, Rotorua, New Zealand, 1999. p. 97-103.

[8] Sanchez FG, Carter EA, Klepac J. Soil carbon and soil physical properties response to forest slash incorporation. New Zealand Journal Forestry Science 2000;30(1-2): $150-68$

[9] Sanchez FG, Carter EA, Edwards TW. Utilization of forest slash to sequester carbon in loblolly pine plantations in the lower coastal plain. In: Proceedings of the First National Conference on Carbon Sequestration. Department of Energy, National Energy Technology Laboratory, Washington, DC, 2001, submitted.

[10] Elliot ET. Aggregate structure and carbon, nitrogen and phosphorus in native and cultivated soils. Soil Science Society America Journal 1986;50:627-33.

[11] Beare MH, Hendrix PF, Coleman DC. Water stable aggregates and organic matter fractions in conventional and no-tillage soils. Soil Science Society America Journal 1994;58:777-86.

[12] Hassink J, Whitmore AP. A model of the physical protection of organic matter in soils. Soil Science Society America Journal 1997;61:131-9.

[13] Van Veen JA, Ladd JN, Amato $M$. Turnover of carbon and nitrogen through the microbial biomass in a sandy loam and a clay soil incubated with $\left[{ }^{14} \mathrm{C}(\mathrm{U})\right]$ glucose and $\left[{ }^{15} \mathrm{~N}\right]\left(\mathrm{NH}_{4}\right)_{2} \mathrm{SO}_{4}$ under different moisture regimes. Soil Biology and Biochemistry 1985;17:257-74.

[14] Verberne ELJ, Hassink J, Willigen PDE, Groot JJR, Van Veen JA. Modelling organic matter dynamics in different soils. Netherlands Journal Agricultural Science 1990;38: 221-38.

[15] McDaniel PA, Munn LC. Effect of temperature on organic carbon-texture relationships in Mollisols and Aridisols. Soil Science Society America Journal 1985;49:1486-9.

[16] Amelung W, Flach KW, Zech W. Climatic effects on soil organic matter composition in the Great Plains. Soil Science Society America Journal 1997;61:115-23.

[17] Bauer A, Black AL. Quantification of the effect of soil organic matter content on soil productivity. Soil Science Society America Journal 1994;58:185-93.

[18] Cole DW, Rapp M. Elemental Cycling. In: Riechle DE, editor. Dynamic properties of forest ecosystem. Cambridge, UK: Cambridge University Press, 1981. p. 341-409.

[19] Edmonds RL, Hsiang T. Forest floor and soil influences on response of Douglas-fir to urea. Soil Science Society America Journal 1987;51:1332-7.

[20] Binkley D, Hart SC. The components of nitrogen availability assessments in forest soils. Advances in Soil Science 1989;10:57-112.

[21] Ruark GA, Blake JI. Conceptual stand model of plant carbon allocation with a feedback linkage to soil organic matter maintenance. In: Dyck WJ, Mees CA, editors. Proceedings of IEA/BE T6/A6 Wokshop (Florida USA): Long-tern Field Trials to Assess Environmental Impacts of Harvesting. Forest Research Bulletin Number 161. Forest Research Institute, Rotorua, New Zealand, 1991. p. 187-98.

[22] Wander MM, Traina SJ, Stinner BR, Peters SE. Organic and conventional management effects on biologically active soil organic matter pools. Soil Science Society America Joumal 1994;58:1130-9.

[23] Eswaran H, Van den Berg E, Reich P, Kimble J. Global soil carbon resources. In: Lal R, Kimble J, Levine E, Stewart $\mathrm{BA}$, editors. Soils and global change. Boca Raton, FL: CRC Press, Inc, 1995. p. 440.

[24] Johnson DW. Effects of forest management on soil carbon storage. Water Air Soil Pollution 1992;64:83-120. 
[25] Soil Survey Staff. Keys to soil taxonomy, 7th ed. Blacksburg, VA: Pocahontos Press, Inc., 1997. p. 545.

[26] Brown JK. Handbook for inventorying downed woody material. General Technical Report INT-16. Ogden, Utah: United States Department of Agriculture-Forest Service, 1974. p. 24.

[27] Soil and Plant Analysis Council, Inc. Soil analysis: handbook of reference methods. Boca Raton, FL: St. Lucie Press, 2000. p. 247.

[28] Blake GR Hartge KH. Bulk Density. In: Klute A, editor. Methods of soil analysis, Part 1. 2nd ed. Madison, WI: American Society of Agronomy, 1986. p. 363-75.

[29] Gee GW, Bauder JW. Particle-size analysis. In: Klute A, editor. Methods of Soil Analysis, Part 1. 2nd ed. Madison, WI: American Society of Agronomy, 1986. p. $377-81$.

[30] American Society of Agricultural Engineers. Soil cone penetrometer. St. Joseph, MI: American Society of Agricultural Engineers Standards S313. 2, 2000, p. 832-3.

[31] McNabb K. Site preparation for plantation establishment. Forest Landowner 1998;57(5):12-3.
[32] Sanchez FG. Loblolly pine needle decomposition as affected by irrigation, fertilization, and substrate quality. Forest Ecology and Management 2001;5349:1-12.

[33] Henderson C, Levett A, Lisle D. The effects of soil water content and bulk density on the compactibility and soil penetration resistance of some western Australian sandy soils. Australian Joumal of Soil Research 1988;26:391-400.

[34] Panayiotopoulos KP, Mullins CE. Packing of sands. Journal of Soil Science 1985;36:129-39.

[35] Ayers PD, Perumpral JV. Moisture and density effect on cone index. Transactions of the American Society of Agricultural Engineers 1982;25:1169-72.

[36] Morris LA, Lowery RF. Influence of site preparation and soil conditions affecting stand establishment and tree growth. Southern Journal of Applied Forestry 1988;12:170-8.

[37] Hom R, Domzal H, Slowinska-Jurkiewicz A, van Ouwerkerk C. Soil compaction processes and their effects on the structure of arable soils and the environment. Soil Tillage Research 1995;35:23-36.

[38] Greacen EL, Sands R. Compaction of forest soils. A review. Australian Journal of Soil Research 1980;18:163-89. 